\title{
Tualang Honey Improves Memory and Prevents Hippocampal Changes in Prenatally Stressed Rats
}

\author{
Prenatal Olarak Strese Maruz Kalan Erişkin Sıçanlarda Tualang Balının \\ Hafızayı Güçlendirmesi ve Hippokampal Değişiklikleri Önlemesi
}

\author{
(D) Che Badariah ABD AZIZ*, (D) Hidani HASIM, (D) Rahimah ZAKARIA, (D) Asma Hayati AHMAD \\ Department of Physiology, Universiti Sains Malaysia, Kelantan, Malaysia
}

\begin{abstract}
Objectives: This study investigated whether the alterations in memory and hippocampus morphology and levels of malondialdehyde (MDA) and $\mathrm{N}$-methyl-D-aspartate (NMDA) receptor in the hippocampus of adult rats after prenatal stress could be prevented by administration of Tualang honey $(\mathrm{TH})$.

Materials and Methods: Twenty-four pregnant rats were randomly grouped into a control group (C), a stress group (S), and a stress group treated with TH. Eight male pups from each group were randomly chosen and they were sacrificed at eight or ten weeks of age following the novel object recognition test. Their brains were removed and histological changes and levels of MDA and NMDA receptors in the hippocampus were determined. Results: The offspring from $\mathrm{TH}$ group showed significantly increased preference index $(p<0.05)$ with higher neuronal number compared to $S$ group. A significantly lower level of MDA and NMDA receptors were shown in TH group ( $P<0.01 ; \mathrm{P}<0.05$ respectively) compared to $\mathrm{S}$ group. The parameters investigated were not significantly different between $\mathrm{C}$ and $\mathrm{TH}$ groups.

Conclusion: The study has shown that memory alteration, changes in hippocampus histology, MDA and NMDA receptor levels could be prevented by TH administration during prenatal stress. The results suggest the beneficial effects of Tualang honey in prenatally stressed rat offspring.
\end{abstract}

Key words: Prenatal stress, hippocampus, Tualang honey, malondialdehyde, NMDA receptor

\section{öz}

Amaç: Bu çalışma prenatal olarak strese maruz kalan erişkin sıçanlarda Tualang balı (TH) uygulamasının hafıza ve hippokampal morfoloji değişikliklerini ve malondialdehit ve N-metil-D-aspartat (NMDA) reseptör düzeylerindeki farklılıları önleyip önlemeyeceğini belirlemek için gerçekleştirilmiștir.

Gereç ve Yöntemler: Yirmi dört gebe sıçan kontrol grubu (C), stres grubu (S) ve TH uygulanan stres grubu olarak randomize olarak gruplanmıştır. Bu annelerden doğan 24 yavru erişkinliğe geldiklerinde yeni obje tanıma testi yapıldıktan sonra sakrifiye edilmiştir. Beyinleri çıkartılmış ve histopatolojik değişiklikler, MDA ve hipokampüsteki NMDA reseptör düzeyleri belirlenmiștir.

Bulgular: TH grubundan alınan yavrular, S grubuna kıyasla daha yüksek nöron sayısı ile belirgin bir şekilde artmış tercih indeksi (p<0.05) göstermiștir. TH grubundan alınan yavrularda, S grubuna göre MDA ve NDMA reseptör düzeylerinin belirgin bir şekilde düșük olduğu görülmüștür (sırasıyla $p<0,01$ ve $p<0,05)$. İncelenen parametreler arasında $\mathrm{C}$ ve TH grupları arasında fark yoktur.

Sonuç: Bu çalışma, prenatal stres esnasında hafıza değişikliği, hipokampus histolojisi, MDA ve NMDA reseptör seviyelerindeki değişikliklerin TH uygulamasıyla önlenebileceğini göstermiștir. Bulgular, prenatal stresli sıçan yavrularında TH'nin faydalı etkilerini göstermektedir.

Anahtar kelimeler: Prenatal stres, hipokampüs, Tualang balı, malondialdehit, NDMA reseptörü

*Correspondence: E-mail: badariah@usm.my, Phone: 609-7676176 ORCID-ID: orcid.org/0000-0003-0102-1594

Received: 20.06.2019, Accepted: 31.10.2019

๑Turk J Pharm Sci, Published by Galenos Publishing House. 


\section{INTRODUCTION}

Studies have reported that prenatal stress might lead to development of abnormal behaviors in adult offspring such as attention deficit hyperactivity disorder, schizophrenia, and depression as well as disruption of learning and memory processing of spatial information in the offspring. ${ }^{1-3}$ The mechanisms that are responsible for the behavioral abnormalities following prenatal stress might be related to higher maternal corticosterone levels and lower placental 11- $\beta$-hydroxysteroid dehydrogenase type 2, an enzyme that deactivates the maternal corticosterone. ${ }^{4}$ Changes in the hormone and enzyme will lead to higher levels of corticosterone in the fetus. Prolonged exposure to corticosterone will alter growth of the fetal brain and lead to oxidative stress as shown by increased lipid peroxidation and reduced in enzymatic antioxidant activities in the brain.,

The oxidative stress may contribute to damage of the neurons in the hippocampus of offspring and impairment of memory function. ${ }^{7}$ Another report has shown that stress-induced elevation of $\mathrm{N}$-methyl-D-aspartate (NMDA) receptors and corticosterone might mediate reduced learning ability, impaired memory, and other stress-induced neurologic disorders. ${ }^{8}$ Studies have demonstrated that the hippocampus of prenatally stressed animals, e.g. rats and monkeys, was smaller compared to that of the nonstressed group and this suggests that prenatal stress is associated with reduced neurogenesis., ${ }^{910}$ The reduced neurogenesis that occurs following prenatal stress might be associated with oxidative stress in the brain and with impairment of memory function. 5,6,8

Tualang honey $(\mathrm{TH})$ is a wild rainforest multifloral honey produced by bees of the species Apis dorsata. The honey can be collected from the hives, which are built on the branches of Tualang trees (Koompassia excelsa). It contains fructose, glucose, maltose, amino acids, vitamins, minerals, enzymes, flavonoids, and phenolic acids.11,12 The composition will depend on the floral source and the environment surrounding the trees. ${ }^{13,14} \mathrm{TH}$ has been reported to have more antioxidant activity compared to Gelam and Manuka honey, which are monofloral honeys. ${ }^{12,15}$

Although direct administration of $\mathrm{TH}$ has been reported to reduce oxidant levels in stressed ovariectomized rats and improve memory function in ageing rats, its role in improving memory function in prenatally stressed rat offspring is not known. ${ }^{16,17}$ Hence, this study investigated whether alteration of recognition memory and changes in morphology as well as malondialdehyde (MDA) and NMDA receptor levels in the hippocampus of adult rat offspring following prenatal stress could be prevented by $\mathrm{TH}$ administration to the pregnant dams.

\section{MATERIALS AND METHODS}

Twenty-four female and six male Sprague Dawley rats, 8 to 10 weeks of age, were obtained from the Animal Research and Service Centre (ARASC), Universiti Sains Malaysia. The rats were maintained on a 12-h light:12-h dark cycle (light phase 0700-1900) with adequate food and water available ad libitum with an adaptation phase for 3-5 days in the physiology laboratory before the experiment. The experiments were done in ARASC dring the day time. After mating, vaginal smears from the female rats were assessed in the morning between 0900 and 1000, and if sperms were detected, the day was labeled as day 0 of pregnancy. ${ }^{18}$

The rats were randomized into three groups ( $n=8$ per group): control, stress, and stress treated with honey (TH). The stress was applied in the form of repeated restraint stress in a cylindrical restrainer measuring $23 \mathrm{~cm} \times 6 \mathrm{~cm}$. The stress was applied to the pregnant dams three times daily: 30 min each at 0800,1200 , and $1600 .^{18}$ The Federal Agricultural Marketing Authority supplied the $\mathrm{TH}$. It was administered orally by gavaging to the pregnant rats (stress treated group) throughout pregnancy until delivery. The dosage used was $1.2 \mathrm{~g} / \mathrm{kg}$ body weight/day and it was in the form of undiluted honey. ${ }^{18}$ Each pregnant dam was kept in an individual cage until delivery. At least one male offspring from each pregnant dam was included in the study. A total of 24 male offspring ( 8 to 10 weeks old) weighing $200 \mathrm{~g}$ to $250 \mathrm{~g}$ were investigated.

\section{Novel object recognition test (NORT)}

Each rat was adapted to an empty open field $(35 \mathrm{~cm} \times 60 \mathrm{~cm})$ for 10 $\mathrm{min} /$ day for 2 consecutive days. The open field was used for training and retention sessions. During the training session, two objects were placed in the field and each rat was permitted to explore freely for $10 \mathrm{~min}$. The rats' behavior was recorded using a video camera and the time used to explore was assessed from the recorded video. Exploration was defined as the orientation of the animal's snout toward the object, sniffing, or touching with the snout. ${ }^{19}$

Retention was tested a day after the training session. One of the objects used in the training was substituted by a different object (novel object) and each rat was permitted to explore for 5 min. ${ }^{20}$ The objects, which varied in shape and color and were made of plastic, were fixed to the floor. The objects were cleaned before each test to ensure lack of olfactory cues. The present study looked at exploratory preference, the ratio of time spent exploring any one of the two objects (training) or the novel one (retention) over the total time spent exploring both objects. ${ }^{21}$ The preference index $(\mathrm{PI})$ used was an indicator of recognition memory and Hammond et al. ${ }^{22}$ suggested that a PI above 50\% indicates novel object preference, below 50\% familiar object preference, and $50 \%$ no preference.

\section{Morphology of the hippocampus}

The hippocampus was quickly identified and isolated. Ten percent formalin was used to fix the samples. The samples were then dehydrated in an automated tissue processor machine, blocked with paraffin wax, and kept at $0^{\circ} \mathrm{C}$ for $3 \mathrm{~h}$. The tissues were cut using a microtome so that each section was about 5 $\mu \mathrm{m}$ thick. The tissues were then placed on glass slides, dried on a hot plate at $50-55^{\circ} \mathrm{C}$ for $30 \mathrm{~min}$, and kept at $37^{\circ} \mathrm{C}$. The slides were then stained using Nissl staining. After being completely dried of xylene, the slides were air-dried for $30 \mathrm{~min}$, mounted in Cytoseal XYL mounting medium, and covered with cover slips. A light microscope was used to observe the histology of 
the tissues and images were captured to assess the neuronal shape and arrangement.

Preparation of brain homogenate and malondialdehyde measurement

The hippocampus from each animal in each group was quickly removed from the brain. The isolated hippocampus was weighed and homogenate $(10 \% \mathrm{w} / \mathrm{v})$ was prepared in ice-cold $0.1 \mathrm{M}$ phosphate-buffered saline $(\mathrm{pH} \mathrm{7.4)}$ by hand or grinder until no visible particles remained. The homogenates were centrifuged $(10,000 \times \mathrm{g})$ for $10 \mathrm{~min}$ and the samples were stored at $-80^{\circ} \mathrm{C}$ until assayed. The MDA level was analyzed in the hippocampus using commercially available kits (USCNK, Wuhan).

\section{Assay procedures for $N$-methyl-D-aspartate receptors}

The isolated hippocampus was homogenized and the sample was centrifuged at 2,000-3,000 rpm for $20 \mathrm{~min}$. Supernatant was taken and kept at $-80^{\circ} \mathrm{C}$ until the assay. The assay was performed using a reagent kit bought from USCNK (Qayee-Bio, Shanghai, China). The NMDA receptor level in the sample was determined using a double antibody sandwich enzyme-linked immunosorbent one-step process.

\section{Statistical analysis}

The results were analyzed using SPSS version 22. One-Way ANOVA was used to analyze differences in the PI, number of Nissl-positive neurons, and MDA and NMDA receptor levels between the groups. The data were expressed as mean \pm standard error of the mean. The differences were considered to be significant when $p$ was less than 0.05 .

\section{RESULTS}

Effect on the novel object recognition test in prenatally stressed male rat offspring

During the training session for the NORT, there were no significant differences in the PI $(p=0.787)$ between the three groups. The $\mathrm{Pl}$ for the novel object in the stress group was significantly lower $[F(2.30)=0.007, p<0.01]$ compared to the other groups (Figure 1) during the retention session. The $\mathrm{TH}$ group spent significantly longer time exploring the novel object than the stress group did ( $p<0.05)$, while the difference between the $\mathrm{TH}$ and control groups was not statistically significant.

Effect on malondialdehyde level in prenatally stressed male rat offspring

There was a significant difference in MDA level when compared among the groups as determined by One-Way ANOVA $[F(2.21)=18.53, p=0.001]$. The level of MDA in the stress group $(377.55 \pm 9.28 \mathrm{pmol} / \mathrm{mL})$ was significantly higher ( $p<0.01)$ compared to the control $(327.55 \pm 9.24 \mathrm{pmol} / \mathrm{mL}$ ) and $\mathrm{TH}(297.75 \pm 9.61 \mathrm{pmol} / \mathrm{mL})$ groups when analyzed using the Bonferroni post hoc test. There was no significant difference $(p=0.116)$ between the control and TH groups (Figure 2).

Effect on N-methyl-D-aspartate receptor level in prenatally stressed male rat offspring

There was a significant difference in NMDA receptor level when compared among the groups as determined by One-Way

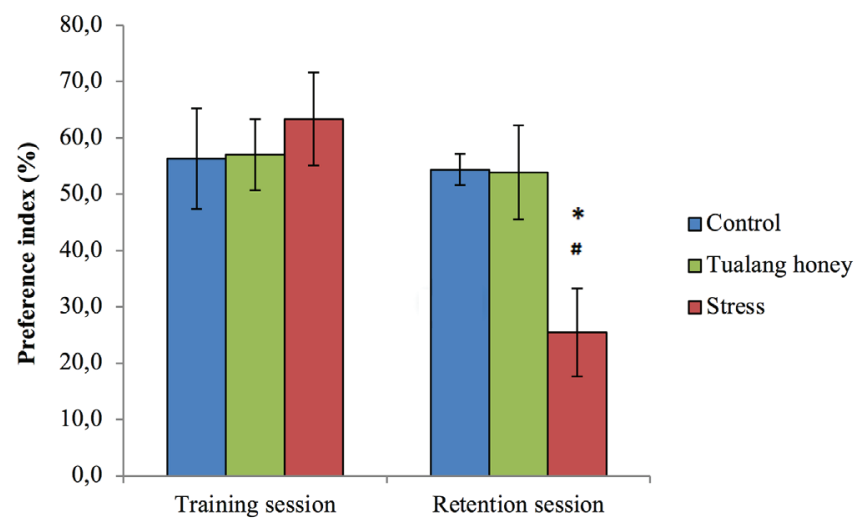

Figure 1. Preference index during training and retention sessions in the offspring from the control, stress and Tualang honey $(\mathrm{TH})$ groups. Preference index $(\%)=a n y$ object/(familiar object $1+$ familiar object 2$) \times 100(\%)$ in the training session or novel object/(familiar object + novel object) $\times 100(\%)$ in the retention session. * $\mathrm{p}<0.05$ shows a significant difference between control and stress; \#p<0.05 shows a significant difference between $\mathrm{TH}$ and stress. Data were analyzed using One-Way ANOVA followed by the Bonferroni test. Data are displayed as mean \pm standard error of the mean for 8 rats in each group

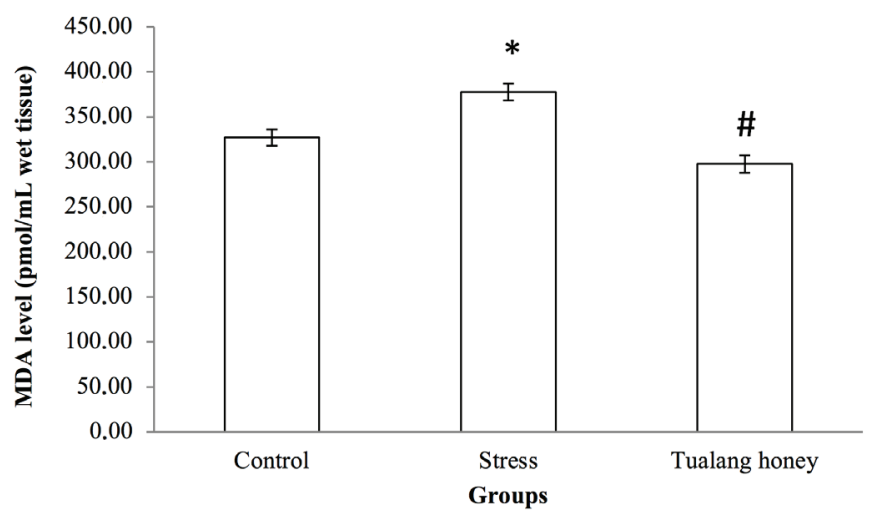

Figure 2. Level of malondialdehyde in the hippocampus of offspring from the control, stress, and Tualang honey $(\mathrm{TH})$ groups. * $\mathrm{p}<0.01$ comparison between control and stress groups and \#p<0.01 comparison between stress treated with $\mathrm{TH}$ and stress group. Data were analyzed using OneWay ANOVA followed by the Bonferroni test. Data are represented as mean \pm standard error of the mean for 8 rats in each group

MDA: Malondialdehyde

ANOVA $[F(2.21)=7.039, p=0.05]$. The level of NMDA receptor was significantly higher in the stress group (20764.34 \pm 788.10 $\mathrm{ng} / \mathrm{mL}$ ) ( $\mathrm{p}<0.05$ ) compared to the control $(18003.45 \pm 561.83$ $\mathrm{ng} / \mathrm{mL})$ and $\mathrm{TH}(16999.95 \pm 826.28 \mathrm{ng} / \mathrm{mL})$ groups (Figure 3) as analyzed using the Bonferroni post hoc test. There was no significant difference $(p=1.000)$ between the control and $\mathrm{TH}$ groups.

Effect on Nissl-positive neurons in the hippocampus of prenatally stressed male rat offspring

There was a significant difference in Nissl-positive neurons when compared among the groups as determined by OneWay ANOVA $[F(2.21)=5.136, p<0.05]$. The Bonferroni post hoc test revealed that the number of Nissl-positive neuron in the stress group $\left(29.66 \pm 1.24 \mathrm{~mm}^{2}\right)$ was significantly lower 
( $p<0.05)$ compared to the $\mathrm{TH}\left(36.67 \pm 1.67 \mathrm{~mm}^{2}\right)$ group (Figure 4). However, there was no significant difference among the control, stress ( $p=1.000)$ and TH ( $p=0.127)$ groups. Meanwhile, normal hippocampus morphology was observed in the control group with abundant healthy neurons. The architecture was maintained and Nissl substances were clearly visualized in the cytoplasm. In contrast, the density and intensity of cytoplasmic staining of the hippocampus in the stress group were reduced

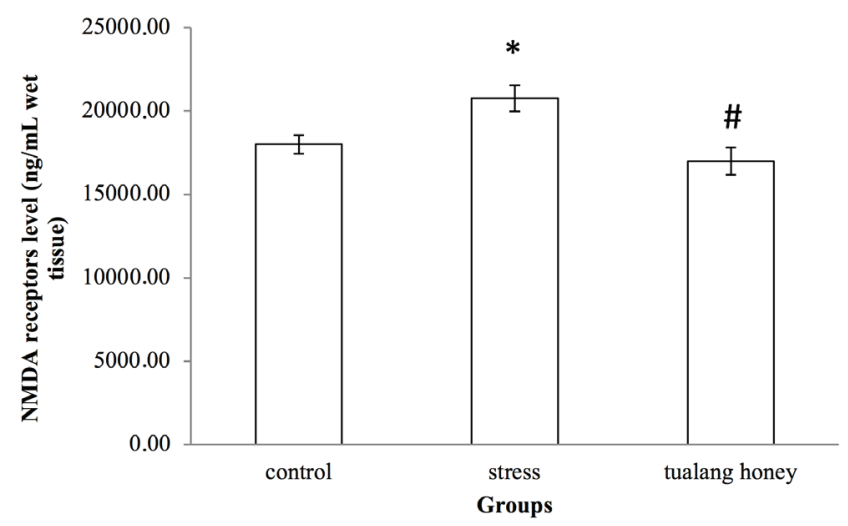

Figure 3. Level of $\mathrm{N}$-methyl-D-aspartate receptors in the hippocampus of offspring from the control, stress, and Tualang honey (TH) groups. ${ }^{*} p<0.01$ comparison between the control and stress groups and \#p<0.01 comparison between the stress treated with $\mathrm{TH}$ and stress groups. Data were analyzed using One-Way ANOVA followed by the Bonferroni test. Data are represented as mean \pm standard error of the mean for 8 rats in each group

NMDA: N-methyl-D-aspartate

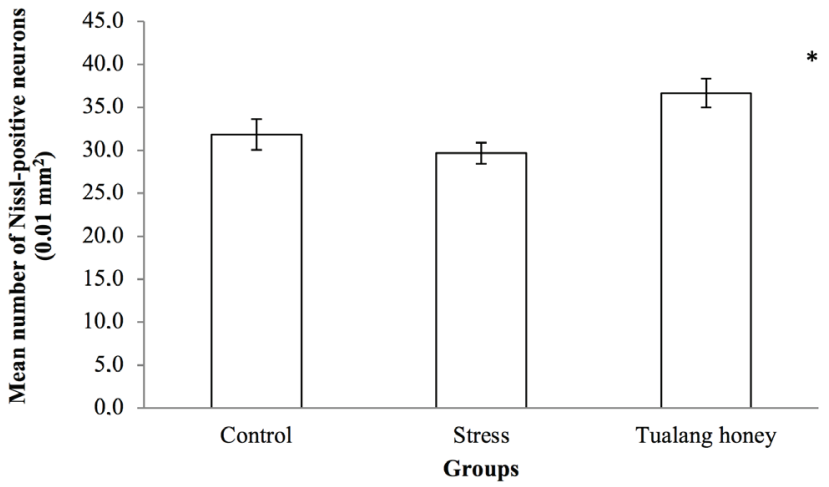

Figure 4. Mean number of Nissl-positive neurons in the hippocampus of offspring from the control, stress, and Tualang honey (TH) groups. ${ }^{*}<0.05$ comparison between the stress and TH groups. Data were analyzed using One-Way ANOVA followed by the Bonferroni test. Data are represented as mean \pm standard error of the mean for 8 rats in each group

with altered architecture compared to the control group. In the $\mathrm{TH}$ group the architecture was preserved with an increased number of neurons (Figure 5).

\section{DISCUSSION}

Recognition memory plays an important role in discriminating familiar from novel stimuli. ${ }^{20}$ In the present study, there was no difference in the PI during the training session for the
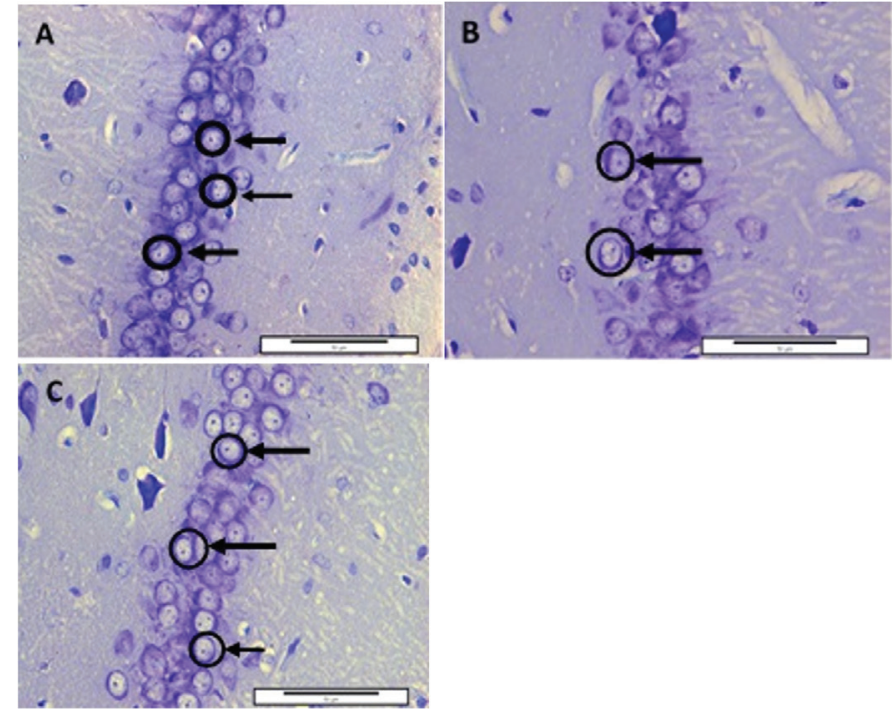

Figure 5. Neurons arrangement in the $\mathrm{CA} 1$ and $\mathrm{CA} 2$ (left side) of hippocampus section of the offspring from A) control, B) stress, and C) stress treated with Tualang honey $(\mathrm{TH})$ groups. The arrows indicate the cells of interest (Nissl staining $\times 400$, scale bar: $50 \mu \mathrm{m}$ ). Note the normal architecture with layers of pyramidal cells and vesicular nuclei in A). The architecture was altered and there was reduced intensity of cytoplasmic staining in B). The architecture was preserved with increased number of cells in C)

NORT; however, $24 \mathrm{~h}$ later the index was significantly lower in the stress group compared to the control and treated stress groups. The reduced $\mathrm{Pl}$ indicating reduced recognition memory most probably is contributed to by structural changes in the hippocampus. ${ }^{21}$ Although the number of Nissl-positive neurons was not significantly different between the stress and control groups, there were altered characteristics of the neuronal cells. Prenatal stress has been shown to induce histological changes in the brain of rat offspring, e.g., the amygdala, corpus callosum cerebral cortex, and hippocampus. ${ }^{23}$

In the present study, the number of Nissl-positive neurons in the stress group was not significantly different, but the morphology of CA2 of the hippocampus was altered. The altered morphology in the hippocampus could be attributed to oxidative stress as shown by the increased MDA level. Neuronal death due to oxidative stress has been shown to occur in the hippocampus in a rat model of status epilepticus and Alzheimer's disease. ${ }^{24,25}$ Exposure to prenatal stress will activate the hypothalamicpituitary-adrenal axis, leading to an increase in glucocorticoid level. There are abundant glucocorticoid receptors in the hippocampus and the hormone is able to modify neuronal structure and neuronal metabolism and may lead to oxidative stress in the brain of the offspring. ${ }^{26}$ Furthermore, increased fetal glucocorticoid may increase activation of excitatory amino acid receptors such as NMDA receptors that upregulate increases in intracellular calcium concentration, contributing to accumulation of oxidants. ${ }^{8}$

The altered morphology of hippocampal cells may influence learning and memory in offspring as shown in the present study. Previous studies have shown that $\mathrm{TH}$ administration improved the number and histological features of neurons in the 
hippocampus of rats exposed to various types of stress. ${ }^{27,28} \mathrm{An}$ increased number of neurons was also seen in the spinal cord of the offspring following $\mathrm{TH}$ administration during prenatal stress. ${ }^{29}$ Luteolin, one of the flavonoids in $\mathrm{TH}$, has been shown to stimulate neurogenesis in the hippocampus of a mouse model of Down's syndrome. ${ }^{16,30}$ The increased neurogenesis was associated with improved learning and memory behavior. ${ }^{30}$ The increased number of hippocampal neurons following $\mathrm{TH}$ administration in the pregnant dams suggests increased neurogenesis in the rats' offspring, which is associated with improved recognition memory.

Quercetin, another flavonoid in $\mathrm{TH}$, has been reported to suppress mRNA expression of corticotropin-releasing hormone and reduce the level of adrenocorticotropic hormone and corticosterone. ${ }^{31}$ A lower level of corticosterone plus the antioxidant activity of $\mathrm{TH}$ would reduce formation of reactive oxygen species and antioxidant utilization in the brain of the offspring, which may protect neuronal function. 29,32 Apart from quercetin and luteolin, TH contains other substances such as caffeic acid and vitamin C. 16,17 Koga et al. ${ }^{33}$ reported that administration of caffeic acid in a group of mice led to reduced oxidative stress and less microglial activation in the hippocampus. Oxidative stress and microglial activation have been linked with various neurological and psychiatric disorders. ${ }^{33}$ Vitamin $\mathrm{C}$ has also been shown to reduce oxidative stress and increase neurogenesis in the hippocampus in a rat model of aging. ${ }^{16,34}$ All the reports suggest that the substances present in $\mathrm{TH}$ have beneficial effects on neurogenesis and have the potential to mitigate oxidative stress.

\section{Study Limitations}

The present study was conducted on a male offspring population and excluded a female population to avoid the influence of ovarian hormones on memory performance. In addition, no NMDA receptor subtype such as NR1 was assessed in this study because of financial limitations. Hence, it is recommended for future studies to investigate the effects of $\mathrm{TH}$ on different subtypes of NMDA receptor and different types of genes responsible for memory performance.

\section{CONCLUSION}

The present study has shown that prenatal stress was associated with memory impairment probably contributed to by altered hippocampal histology and increased levels of MDA and NMDA receptors in the hippocampus. Administration of $\mathrm{TH}$ was associated with improvements in the parameters investigated.

\section{ACKNOWLEDGMENTS}

This study was supported by a Bridging Grant (304/ PPSP/6316130) awarded by Universiti Sains Malaysia.

Conflicts of interest: No conflict of interest was declared by the authors. The authors alone are responsible for the content and writing of the paper.

\section{REFERENCES}

1. Lodge DJ, Grace AA. Developmental pathology, dopamine, stress and schizophrenia. Int J Dev Neurosci. 2011;29:207-213.

2. Sternberg WF, Ridgway CG. Effects of gestational stress and neonatal handling on pain, analgesia, and stress behavior of adult mice. Physiol Behav. 2003;78:375-383.

3. de los Angeles GAM, del Carmen ROM, Sonia GA, RM S. Prenatal stress reduces learning and memory in pre-pubertal, young and adult rats of both sexes. Glob J Zool. 2017;2:13-20.

4. Mairesse J, Lesage J, Breton C, Bréant B, Hahn T, Darnaudéry M, Dickson SL, Seckl J, Blondeau B, Vieau D, Maccari S, Viltart O. Maternal stress alters endocrine function of the feto-placental unit in rats. Am J Physiol Endocrinol Metab. 2007;292:E1526-E1533.

5. Bingham BC, Sheela Rani CS, Frazer A, Strong R, Morilak DA. Exogenous prenatal corticosterone exposure mimics the effects of prenatal stress on adult brain stress response systems and fear extinction behavior. Psychoneuroendocrinology. 2013;38:2746-2757.

6. Sahu S, Madhyastha S, Rao G. Effect of prenatal stress on expression of glutathione system in neonatal rat brain. Turk Neurosurg. 2012;22:576582.

7. Zhu Z, Li X, Chen W Zhao Y, Li H, Qing C, Jia N, Bai Z, Liu J. Prenatal stress causes gender-dependent neuronal loss and oxidative stress in rat hippocampus. J Neurosci Res. 2004;78:837-844.

8. Tavassoli E, Saboory E, Teshfam M, Rasmi Y, Roshan-Milani S, Ilkhanizadeh B. Effect of prenatal stress on density of NMDA receptors in rat brain. Int J Dev Neurosci. 2013;31:790-795.

9. Coe CL, Kramer M, Czeh B. Prenatal stress diminishes neurogenesis in the dentate gyrus of juvenile rhesus monkeys. Biol Psychiatry. 2003;54:1025-1034.

10. Lemaire V, Koehl M, Le Moal M, Abrous DN. Prenatal stress produces learning deficits associated with an inhibition of neurogenesis in the hippocampus. PNAS. 2000;97:11032-11037.

11. Ahmed S, Othman NH. Review of the medicinal effects of tualang honey and a comparison with manuka honey. Malays J Med Sc. 2013;20:6-13.

12. Khalil M, Alam N, Moniruzzaman M, Sulaiman S, Gan S. Phenolic acid composition and antioxidant properties of Malaysian honeys. J Food Sci. 2011;76:C921-C928.

13. Gheldof N, Wang XH, Engeseth NJ. Identification and quantification of antioxidant components of honeys from various floral sources. J Agric Food Chem. 2002;50:5870-5877.

14. Nurul SM, Gan S, Halim A, Shah NSM, Sukari H. Analysis of volatile compounds of Malaysian Tualang (Koompassia excelsa) honey using gas chromatography mass spectrometry. Afr J Tradit Complement Altern Med. 2013;10:180-188.

15. Kishore RK, Halim AS, Syazana MS, Sirajudeen KN. Tualang honey has higher phenolic content and greater radical scavenging activity compared with other honey sources. Nutr Res. 2011;31:322-325.

16. Azman KF, Zakaria R, Abdul Aziz CB, Othman Z. Tualang honey attenuates noise stress-induced memory deficits in aged rats. Oxid Med Cell Longev. 2016;11.

17. Al-Rahbi B, Zakaria R, Othman Z, Hassan A, Ahmad AH. Protective effects of Tualang honey against oxidative stress and anxiety-like behaviour in stressed ovariectomized rats. Int Sch Res Notices. 2014;Published online 2014 Sep 9. doi: 10.1155/2014/521065 
18. Abd Aziz CB, Ahmad R, Mohamed M, Wan Yusof WN. The effects of Tualang honey intake during prenatal stress on pain responses in the rat offsprings. Eur J Integr Med. 2013;5:326-331.

19. Ennaceur A, Delacour J. A new one-trial test for neurobiological studies of memory in rats. 1. Behavioral data. Behav Brain Res. 1988;31:47-59.

20. Antunes M, Biala G. The novel object recognition memory: neurobiology, test procedure, and its modifications. Cogn Process. 2012;13:93-110.

21. Zhao D, Liu D, Chen X Wang K, Zhang A, Kang J, Zhou Q, Duan T. Prenatal stress disturbs hippocampal KIF17 and NR2B in spatial cognition in male offspring. J Neurosci Res. 2013;91:535-544.

22. Hammond RS, Tull LE, Stackman RW. On the delay-dependent involvement of the hippocampus in object recognition memory. Neurobiol Learn Mem. 2004;82:26-34.

23. Charil A, Laplante DP, Vaillancourt C, King S. Prenatal stress and brain development. Brain Res Rev. 2010;65:56-79.

24. Liu J, Wang A, Li L, Huang Y, Xue P, Hao A. Oxidative stress mediates hippocampal neuron death in rats after lithium-pilocarpine-induced status epilepticus. Seizure. 2010;19:165-172.

25. Yang R, Wang Q, Min L, Sui R, Li J, Liu X. Monosialoanglioside improves memory deficits and relieves oxidative stress in the hippocampus of rat model of Alzheimer's disease. Neurol Sci. 2013;34:1447-1451.

26. Joëls M. Functional actions of corticosteroids in the hippocampus. Eur J Pharmacol. 2008;583:312-321.

27. Al-Rahbi B, Zakaria R, Othman Z, Hassan A, Mohd Ismail ZI, Muthuraju S. Tualang honey supplement improves memory performance and hippocampal morphology in stressed ovariectomized rats. Acta Histochem. 2014;116:79-88.
28. Azman KF, Zakaria R, Othman Z, Abd Aziz CB. Neuroprotective effects of Tualang honey against oxidative stress and memory decline in young and aged rats exposed to noise stress. J Taibah Univ Sci. 2018. https:// doi.org/10.1080/16583655.2018.1465275

29. Abd Aziz CB, Ahmad Suhaimi SQ, Hasim H, Ahmad Ah, Zakaria R. Effects of Tualang honey in modulating nociceptive responses at the spinal cord in offspring of prenatally stressed rats. J Integr Med. 2019;17:66-70.

30. Zhou WB, Miao ZN, Zhang B, Long W, Zheng FX, Kong J, Yu B. Luteolin induces hippocampal neurogenesis in the Ts65Dn mouse model of Down syndrome. Neural Regen Res. 2019;14:613-620.

31. Kawabata K, Kawai Y, Terao J. Suppressive effect of quercetin on acute stress induced hypothalamic-pituitary-adrenal axis response in Wistar rats. J Nutr Biochem. 2010;21:374-380.

32. Tronche C, Piérard C, Coutana M, Chauveau F, Liscia P, Béracochéa D. Increased stress-induced intra-hippocampus corticosterone rise associated with memory impairments in middle-aged mice. Neurobiol Learn Mem. 2010;93:343-351.

33. Koga M, Nakagawa S, Kato A, Kusumi I. Caffeic acid reduces oxidative stress and microglial activation in the mouse hippocampus. Tissue Cell. 2019;60:14-20.

34. Nam SM, Seo M, Seo JS, Rhim H, Nahm SS, Cho IH, Chang BJ, Kim HJ, Choi SH, Nah SY. Ascorbic acid mitigates D-galactose-induced brain aging by increasing hippocampal neurogenesis and improving memory function. Nutrients. 2019;11:E176. 